\title{
Initiating insulin in patients with type 2 diabetes
}

\author{
Adrian N.C. Lau MD, Terence Tang MD, Henry Halapy PharmD, Kevin Thorpe PhD, Catherine H.Y. Yu MD MHSc
}

$\mathrm{T}$ ype 2 diabetes has become a worldwide epidemic ${ }^{1}$ and is associated with multiple complications that can be prevented by modifying risk factors and optimizing glycemic control. ${ }^{2}$ The optimization of glycemic control often requires the use of multiple agents, including insulin.

Insulin is an important component of antihyperglycemic therapy, yet there are many perceived barriers. ${ }^{3}$ Existing guidelines do not specifically address the topic of insulin initiation. ${ }^{4}$ We review and analyze the evidence from randomized controlled trials on insulin initiation and address adverse effects and barriers. We also discuss the selection of an insulin regimen, titration and delivery of care, as well as when and how to combine insulin therapy with oral antihyperglycemic agents. A summary of our systematic review and meta-analysis is available in Box 1.

\section{When should insulin be started?}

Clinical practice guidelines vary as to the recommended criteria for the initiation of insulin therapy in patients with type 2 diabetes. Factors that are considered include the control of blood glucose levels and comorbidities that affect choice of treatment.

\section{Glucose control}

The American Diabetes Association and the European Association for the Study of Diabetes developed a consensus algorithm wherein basal insulin is recommended as a second-line agent if the glycated hemoglobin $\left(\mathrm{HbA}_{1 \mathrm{c}}\right)$ value is greater than $7.0 \%$ after metformin monotherapy. ${ }^{5}$ Similarly, the International Diabetes Federation recommends that insulin be started if optimized oral antihyperglycemic therapy and lifestyle interventions are unable to maintain blood glucose at target levels. ${ }^{6}$ In contrast, the Canadian Diabetes Association recommends that insulin be considered as a first-line agent if the $\mathrm{HbA}_{\mathrm{lc}}$ value is $9.0 \%$ or greater in patients with newly diagnosed diabetes or if there is symptomatic hyperglycemia with metabolic decompensation (defined as polyuria, polydipsia and weight loss), and as a second-line agent if the $\mathrm{HbA}_{\mathrm{lc}}$ is still not at target levels (consensus recommendation). ${ }^{4}$

Although no randomized controlled trials have looked at the impact on cardiovascular outcomes of insulin initiation early in the course of type 2 diabetes, early intensive control of blood glucose levels was assessed in the United Kingdom Prospective Diabetes Study (UKPDS). The study compared intensive glycemic control (with metformin, secretagogue or insulin therapy) and conventional glycemic control in patients with newly diagnosed diabetes and found that those in the intensive treatment group had reduced microvascular and macrovascular complications in long-term follow-up. ${ }^{7.8}$ Early insulin initiation has been shown to improve and preserve $\beta$-cell function, ${ }^{9}$ and the ongoing Outcome Reduction With Initial Glargine Intervention (ORIGIN) trial will assess the impact of an early basal insulin strategy on cardiovascular outcomes. ${ }^{10}$

\section{Comorbidities}

Careful monitoring of glycemic control is necessary when treating diabetes in patients with renal or hepatic failure. Many oral antihyperglycemic agents are contraindicated or require dose modification in these patients, necessitating initiation of insulin therapy. Because insulin is cleared renally, its dose must be reduced to prevent hypoglycemic episodes. ${ }^{11}$ Compensated cirrhosis is associated with insulin resistance and often requires higher doses of insulin, whereas decompensated cirrhosis (associated with complications such as variceal

\section{- Ker POINTS}

- Insulin initiation should be considered early in the course of type 2 diabetes.

- Insulin is an effective and safe agent in reducing glycated hemoglobin $A_{1 c} ;$ although its use is associated with weight gain, it is not associated with an increased risk of hypoglycemia.

- A basal regimen is an ideal start given its simplicity and favourable impact on weight and risk of hypoglycemia; intensification of this regimen will be required over time to maintain glycemic control.

- Combination therapy that includes insulin and oral antihyperglycemic agents reduces weight gain, insulin dose and risk of hypoglycemia. 
hemorrhage, ascites, spontaneous bacterial peritionitis or hepatic encephalopathy) results in reduced metabolism of insulin in the liver and hence would require lower doses of insulin. ${ }^{12}$

\section{What adverse effects have been reported with insulin use?}

Common concerns about the use of insulin include the risk of hypoglycemia and weight gain. Other adverse events, such as congestive heart failure and lipodystrophy, are much less common.

\section{Box 1: Summary of the literature review and meta-analysis}

We performed a systematic review of studies examining the effect of the initiation of subcutaneous insulin therapy on glycemic control, weight gain, risk of hypoglycemia, other adverse effects and diabetic complications in outpatients with type 2 diabetes. We excluded studies involving children, adolescents, or patients with type 1 diabetes or gestational diabetes, as well animal studies and trials of inhaled, intravenous, intraperitoneal or continuous subcutaneous insulin treatment. We focused on studies involving insulin-naive patients in the ambulatory care setting and excluded those comparing various insulin regimens in patients already taking insulin. Details regarding our search strategy and meta-analysis are included in Appendix 1.*

We included 56 studies for quantitative review, and 39 studies and 3 systematic reviews for qualitative review (Appendix $2 *$ ). Study quality is summarized in Appendix 3.* All studies were randomized controlled trials, and most were sponsored by industry.

Methodologic quality varied among the trials. In general, participants were 50-70 years old, had diabetes for 8-10 years and were taking at least one oral antihyperglycemic agent. In our meta-analysis, although some comparisons had high heterogeneity, we used a random-effects model that incorporated this uncertainty in the resulting estimates of treatment effect and confidence intervals.

*The appendices are available at www.cmaj.ca/lookup/suppl/doi:10.1503/cmaj.110779/-/DC1.

Table 1: Prevalence of barriers to the initiation of insulin therapy perceived by patients and physicians ${ }^{13}$

\begin{tabular}{|c|c|c|}
\hline \multirow[b]{2}{*}{ Perceived barrier } & \multicolumn{2}{|c|}{ Prevalence, \% } \\
\hline & $\begin{array}{l}\text { Patients, insulin } \\
\text { naive; users }\end{array}$ & Physicians \\
\hline Fear of hypoglycemia & $12 ; 4$ & 80 \\
\hline $\begin{array}{l}\text { Pain associated with } \\
\text { blood testing }\end{array}$ & $5 ; 7$ & 54 \\
\hline Weight gain & $12 ; 6$ & 26 \\
\hline $\begin{array}{l}\text { Injection-related } \\
\text { pain }\end{array}$ & $12 ; 17$ & 48 \\
\hline Other & $\begin{array}{l}\text { - Diabetes not thought } \\
\text { to be serious: } 47 ; 7 \\
\text { - Fear of addiction to } \\
\text { insulin: } 39 ; 21\end{array}$ & $\begin{array}{l}\text { - Perceived patient } \\
\text { noncompliance: } 92 \\
\text { - Patient too old: } 47 \\
\text { - Diabetes thought to be } \\
\text { too advanced for insulin } \\
\text { to be beneficial: } 12 \\
\text { - Limited experience: } 27\end{array}$ \\
\hline
\end{tabular}

\section{Hypoglycemia}

Fear of hypoglycemia remains a barrier to insulin initiation for patients and physicians, although physicians' perception of this risk is amplified relative to patients (Table 1 ). ${ }^{13}$ The prevalence of hypoglycemia associated with the use of insulin varies widely: from $9 \%$ of patients when defined as a glucose level below $3.1 \mathrm{mmol} / \mathrm{L},{ }^{14}$ to $64 \%$ of patients when defined as a glucose level below $3.0 \mathrm{mmol} / \mathrm{L} .{ }^{15}$ In our meta-analysis comparing insulin use with oral agents used alone, which included data from six studies, the risk of hypoglycemia was higher with insulin (odds ratio [OR] 2.23); however, the wide $95 \%$ confidence interval (95\% CI 0.59 to 8.42 ) and the high level of heterogeneity $\left(I^{2}=89.5 \%\right)$ make this risk difficult to interpret (Table 2).

Risk factors for hypoglycemia include inappropriate dose, timing or type of insulin, decreased glucose delivery (e.g., a missed meal), decreased endogenous glucose production (e.g., alcohol intake), increased glucose utilization (e.g., through exercise), increased insulin sensitivity (e.g., weight loss, treatment with insulin sensitizer) and decreased insulin clearance (e.g., renal failure). ${ }^{57}$ The risk of hypoglycemia can be reduced by addressing these factors. Strategies for preventing hypoglycemia in patients using insulin include asking about hypoglycemia at each visit, education, frequent self-monitoring, individualized glycemic goals and continued professional guidance. ${ }^{57}$

\section{Weight gain}

Weight gain that occurs with the initiation of insulin therapy has been reported to vary from $0.3 \mathrm{~kg}^{43}$ to $6.4 \mathrm{~kg}^{30}$ and may contribute to a patient's reluctance to start using insulin..$^{58}$ Weight gain occurs early — in the first weeks to months after insulin initiation ${ }^{59}$ - then levels off, correlating with the intensity of insulin titration. In one study in which insulin was rapidly titrated over the first 12 weeks, almost $80 \%$ of weight gain occurred during this period. ${ }^{31}$ In contrast, when titration occurred much more slowly, weight gain occurred gradually over the two-year study period. ${ }^{16}$ The amount of weight gained should be tempered by consideration that weight lost previously because of poor glycemic control is regained after the initiation of insulin ${ }^{60}$ and that an increase in lean body mass accounts for $30 \%$ of this weight gain. ${ }^{16,61}$

Risk factors for weight gain include fear of hypoglycemia, depression, use of antidepressants and choice of insulin regimen (Table 1). ${ }^{13}$ Although cardiovascular implications of this weight gain are undefined, weight gain that follows insulin initiation has been correlated with a deterioration in 
cardiometabolic risk factors such as blood pressure and serum levels of triglycerides, low-density lipoprotein (LDL) cholesterol and high-density lipoprotein (HDL) cholesterol. . $^{16,62}$

Strategies to minimize weight gain following insulin initiation include identification of and addressing the fear of hypoglycemia; $;{ }^{58}$ treatment of depression; ${ }^{58}$ selection of weight-neutral antidepressant agents ${ }^{58}$ promotion of regular exercise $;^{58,62}$ dietary modifications, in conjunction with a dietitian, to restrict energy intake and reduce fat intake, ${ }^{58,62}$ particularly for patients with pre-existing obesity; and selection of an appropriate insulin regimen (discussed later in the article). The risk of weight gain can be addressed through the use of an interprofessional approach.

\section{Other reported adverse effects}

Observational studies have reported a number of rare adverse events associated with insulin use, including congestive heart failure, edema, lipodystrophy, allergic reactions, reversible transaminitis, reversible nephrotic syndrome and $\beta$-cell destruction. The prevention and management of these adverse events are summarized in Appendix 4 (available at www.cmaj.ca /lookup/supp1/doi:10.1503/cmaj.110779/-/DC1).

\section{What barriers affect insulin initiation?}

Barriers to insulin initiation exist at the patient, physician and system levels. As mentioned previously, barriers perceived by physicians were amplified compared with patients' perceptions (Table 1). ${ }^{13}$ For example, fear of hypoglycemia, weight gain, and injection-related pain and anxiety were ranked higher as barriers by physicians than by patients, whereas patients' concerns included fear of "addiction" to insulin and a lack of understanding of the seriousness of their disease.

Although quality of life is commonly assumed to be reduced with insulin initiation, quality of life and treatment satisfaction have been found to be unchanged ${ }^{63}$ or improved ${ }^{64,65}$ in randomized controlled trials.

Additional barriers are listed in Table 1. Insulin initiation is often linked to patients' feelings of blame and failure. ${ }^{3}$ Patients may also be deterred by inconvenience and lack of portability of insulin. ${ }^{66}$ The identification and addressing of patient barriers through counselling (including education regarding modern devices for insulin delivery) may improve acceptance by patients..$^{13,66}$

The care of a patient with type 2 diabetes is a

Table 2: Effect of regimens for insulin initiation in type 2 diabetes on the reduction of glycated hemoglobin $A_{1 c}\left(H b A_{1 c}\right)$, weight gain and risk of hypoglycemia

\begin{tabular}{|c|c|c|c|}
\hline Regimen 1 (v. regimen 2) & $\begin{array}{l}\text { Difference in } \mathrm{HbA}_{1 c} \\
\text { reduction, * \% }(95 \% \mathrm{Cl})\end{array}$ & $\begin{array}{l}\text { Difference in weight } \\
\text { gain, }{ }^{*} \mathrm{~kg}(95 \% \mathrm{Cl})\end{array}$ & $\begin{array}{c}\text { Risk of hypoglycemia, } \uparrow \\
\text { OR }(95 \% \mathrm{Cl})\end{array}$ \\
\hline $\begin{array}{l}\text { Insulin (v. oral } \\
\text { antihyperglycemic agents } \ddagger \text { ) }\end{array}$ & $\begin{array}{l}-0.62(-0.97 \text { to }-0.26)^{16-28} \\
(n=1730) \\
l^{2}=74.2 \%\end{array}$ & $\begin{array}{l}2.60(1.31 \text { to } 3.89)^{16-19,23,25,26,29} \\
(n=629) \\
I^{2}=78.2 \%\end{array}$ & $\begin{array}{l}2.23(0.59 \text { to } 8.42)^{21-25,27} \\
(n=1341) \\
l^{2}=89.5 \%\end{array}$ \\
\hline \multicolumn{4}{|l|}{ Choice of regimen } \\
\hline Basal (v. premixed) & $\begin{array}{l}0.30(0.03 \text { to } 0.57)^{14,18,30-40} \\
(n=4193) \\
l^{2}=93.1 \%\end{array}$ & $\begin{array}{l}-1.03(-1.94 \text { to }-0.13)^{14,18,30-39} \\
(n=4140) \\
I^{2}=65.5 \%\end{array}$ & $\begin{array}{l}0.76(0.67 \text { to } 0.87)^{14,30,32,35,39-42} \\
(n=3870) \\
l^{2}=0.0 \%\end{array}$ \\
\hline Basal (v. basal-bolus) & $\begin{array}{l}0.33(0.03 \text { to } 0.63)^{18,19,30,32,43-46} \\
(n=1624) \\
l^{2}=52.0 \%\end{array}$ & $\begin{array}{l}-1.41(-2.05 \text { to }-0.77)^{18,19,30,32,43-46} \\
(n=1627) \\
l^{2}=44.9 \%\end{array}$ & $\begin{array}{l}0.41(0.08 \text { to } 2.04)^{30,32,46} \\
(n=993) \\
l^{2}=82.8 \%\end{array}$ \\
\hline Premixed (v. basal-bolus) & $\begin{array}{l}0.08(-0.16 \text { to } 0.31)^{18,30,47} \\
(n=691) \\
I^{2}=0.0 \%\end{array}$ & Insufficient data & Insufficient data \\
\hline \multicolumn{4}{|l|}{ Choice of basal insulin } \\
\hline $\begin{array}{l}\text { Intermediate } \\
\text { (v. long-acting) }\end{array}$ & $\begin{array}{l}-0.20(-0.42 \text { to } 0.02)^{48-51} \\
(n=925) \\
I^{2}=0.0 \%\end{array}$ & $\begin{array}{l}-0.20(-0.22 \text { to }-0.18)^{48,50-52} \\
(n=1348) \\
I^{2}=0.0 \%\end{array}$ & $\begin{array}{l}1.70(1.19 \text { to } 2.41)^{15,48-50,53} \\
(n=2075) \\
I^{2}=45.1 \%\end{array}$ \\
\hline $\begin{array}{l}\text { Basal, morning (v. basal, } \\
\text { bedtime) }\end{array}$ & $\begin{array}{l}0.06(-0.58 \text { to } 0.71)^{18,49,54} \\
(n=455) \\
l^{2}=34.9 \%\end{array}$ & $\begin{array}{l}-0.93(-13.21 \text { to } 11.35)^{18,54,55} \\
(n=210) \\
I^{2}=71.3 \%\end{array}$ & Insufficient data \\
\hline \multicolumn{4}{|c|}{$\begin{array}{l}\text { Note: } \mathrm{Cl}=\text { confidence interval, } I^{2} \text { value }=\text { measure of heterogeneity of included studies, with larger values indicating increasing heterogeneity, OR = odds ratio. } \\
\text { * Regimen } 1 \text { minus regimen } 2 . \text { If the value is negative, regimen } 1 \text { is favourable; if the value is positive, regimen } 2 \text { is favourable. } \\
\text { tRegimen } 1 \text { divided by regimen } 2 \text {. If the value is }<1 \text {, regimen } 1 \text { is favourable; if the value is }>1 \text {, regimen } 2 \text { is favourable. Various definitions for hypoglycemia } \\
\text { were used in the studies included in the meta-analysis. Some defined it by a particular capillary glucose reading (e.g., }<4.0 \text { mmol/L) with or without symptoms of } \\
\text { hypoglycemia, and others used protocols (e.g., the Diabetes Control and Complications Trial classification system }{ }^{56} \text { ). Severe hypoglycemia was defined as an } \\
\text { episode of hypoglycemia requiring the assistance of another person. } \\
\text { †Metformin, secretagogue, thiazolidinedione or a combination. }\end{array}$} \\
\hline
\end{tabular}


time- and resource-intensive process. ${ }^{13,67}$ Practice- and system-level factors contribute substantially to the successful initiation of insulin therapy. An integrated health care team is required that includes the primary care physician, a diabetes educator and consultants. ${ }^{68}$ The family physician serves as the principal medical contact for the patient and provides continuity of care. The diabetes educator facilitates education programs that support self-management. ${ }^{69,70}$ Shared care with a diabetes specialist has been shown to result in improved glycemic control. ${ }^{71}$ Diabetes case managers can help improve the delivery of care and clinical outcomes by coordinating care and facilitating timely medication changes. ${ }^{72}$

Organizational and technologic interventions such as electronic databases and automated reminders about appointments, investigations and interventions can improve the efficiency and effectiveness of the diabetes health care team. ${ }^{72}$ At a systems level, adequate funding to support comprehensive diabetes health care teams is important. Funding for these teams may be threatened by limited health care resources in the setting of an aging population. ${ }^{73}$

\section{How is the starting regimen chosen?}

Three types of insulin regimen are commonly used: basal, premixed and basal-bolus. Premixed and basal-bolus regimens result in greater reductions in $\mathrm{HbA}_{\mathrm{lc}}$ compared with basal regimens. However, they are associated with more weight gain and, in the case of premixed regimens, an increased risk of hypoglycemia, and are more complex, which may affect adherence (Table 2; see also Appendix 5, available at www.cmaj.ca/lookup/suppl/doi:10.1503/cmaj $.110779 /$ /DC1). We suggest that a basal regimen is the ideal one to start with, given its simplicity and favourable safety profile, recognizing that modifications to this regimen will be required over time to maintain glycemic control. In addition, the acceptability, feasibility and effectiveness of this approach in a primary care setting have been shown and will be detailed later in this paper.

The types of insulin, their pharmacokinetics and regimens are outlined in Appendices 6 and 7 (available at www.cmaj.ca/lookup/suppl/doi :10.1503/cmaj.110779/-/DC1). The effects of various regimens on $\mathrm{HbA}_{1 \mathrm{c}}$, weight gain and risk of hypoglycemia are summarized in Table 2. Data regarding the effect of different regimens on vascular outcomes, lipid profile and quality of life are limited (see Appendix 8, available at www.cmaj.ca /lookup/suppl/doi:10.1503/cmaj.110779/-/DC1).

\section{Choice of regimen}

Our review identified 15 randomized trials that compared basal regimens with premixed regimens (Table 2)..$^{14,18,30-42}$ Patients given a premixed regimen were found to have a greater reduction in $\mathrm{HbA}_{1 c}$, but they also had greater weight gain and a higher risk of hypoglycemia.

Similarly, our analysis of eight randomized trials comparing basal regimens with basal-bolus regimens ${ }^{18,19,30,32,43-46}$ found that the latter were associated with a greater reduction in $\mathrm{HbA}_{1 \mathrm{c}}$, greater weight gain and a trend, although not significant, toward more frequent hypoglycemia (Table 2).

Our analysis of three trials comparing premixed regimens with basal-bolus regimens found no significant difference in effect on $\mathrm{HbA}_{1 \mathrm{c}}{ }^{18,30,47}$ Data were insufficient for a pooled estimate of the effect on weight gain and hypoglycemia, but the individual studies showed no difference between these two regimens on weight gain or risk of hypoglycemia. $^{18,30}$ Thus, although premixed and basalbolus regimens may be better than basal regimens at reducing $\mathrm{HbA}_{\mathrm{c}}$, this strength should be balanced against the increased weight gain associated with both regimens and the increased risk of hypoglycemia associated with premixed regimens.

\section{Choice of insulin}

\section{Basal insulin}

A basal insulin in the form of a long-acting analogue is preferable because it offers glycemic control comparable to that of an intermediateacting insulin but is associated with a lower risk of hypoglycemia. Our analysis of seven randomized trials comparing intermediate- and longacting insulin analogues ${ }^{15,48-53}$ showed that they performed equally in terms of $\mathrm{HbA}_{1 \mathrm{c}}$ reduction (Table 2). Patients taking intermediate-acting analogues had slightly lower weight gain; however, they had significantly more episodes of hypoglycemia (Table 2). A recent Cochrane review comparing intermediate- and long-acting insulins (which did not focus specifically on studies of insulin initiation) reported similar findings: no difference in $\mathrm{HbA}_{\mathrm{lc}}$ reduction, but a significantly greater reduction in hypoglycemic events with the long-acting insulin analogues glargine (OR $0.84,95 \%$ CI 0.75 to 0.95 ) and detemir (OR $0.56,95 \%$ CI 0.42 to 0.74 ). ${ }^{74}$

We identified two studies that compared glargine and detemir for insulin initiation. ${ }^{75,76} \mathrm{~A}$ meta-analysis was not done given the number of studies. These studies showed inconsistent findings: one reported a greater reduction in $\mathrm{HbA}_{\mathrm{lc}}$ of $0.3 \%$ with glargine than with detemir $(p<0.004),{ }^{75}$ but the other found no difference between the two products. ${ }^{76}$ Both studies showed a greater 
weight gain $(0.77-1.37 \mathrm{~kg})$ with glargine than with detemir, but a similar risk of hypoglycemia.

In our analysis of four studies that compared morning with bedtime administration of basal insulin, ${ }^{18,49,54,55}$ we found no significant difference in $\mathrm{HbA}_{1 \mathrm{c}}$ reduction or weight gain. Data were insufficient for a pooled estimate of the effect on hypoglycemia.

\section{Bolus insulin}

Current evidence shows that both rapid-acting and short-acting insulins are reasonable choices for bolus insulin. Rapid-acting analogues more closely mimic physiologic insulin secretion than short-acting ones do. However, the literature has not consistently shown improved glycemic control when comparing insulin initiation with rapid-acting and short-acting insulins. One randomized controlled trial showed reductions in $\mathrm{HbA}_{1 \mathrm{c}}$ but an increased risk of hypoglycemia among patients given rapid-acting insulin. ${ }^{77}$ Another study comparing rapid-acting and shortacting premixed insulin revealed no difference in effect on $\mathrm{HbA}_{1 \mathrm{c}}{ }^{42}$

\section{Who should initiate and titrate insulin?}

Insulin therapy can be initiated by primary care physicians and specialists, and the dose titrated by patients themselves with support from their health care provider. Before initiating insulin therapy, the clinician should ensure that the patient is able to monitor his or her blood glucose level, is aware of the symptoms of hypoglycemia and has adequate knowledge about dealing with these episodes. Patient education can be facilitated by an interprofessional diabetes care team and implementation of organization-level processes of care that enable regular diabetes monitoring and recall (e.g., telephone reminders for upcoming appointments). ${ }^{72}$

In the Implementing New Strategies with Insulin Glargine for Hyperglycaemia Treatment (INSIGHT) trial, patients of either family physicians or diabetes specialists were randomly assigned to receive oral antihyperglycemic agents alone or in combination with insulin glargine. ${ }^{21}$ In a post-hoc analysis of whether patients' outcomes differed depending on the type of physician managing their care, the reductions in $\mathrm{HbA}_{1 \mathrm{c}}$ values and rates of hypoglycemia were comparable among patients who had insulin glargine initiated by either family physicians or diabetes specialists. Similarly, post-hoc analysis of the AT.LANTUS trial (A Trial Comparing Lantus Algorithms to Achieve
Normal Blood Glucose Targets in Subjects With Uncontrolled Blood glucose), which randomly assigned patients to self-titration or clinic-driven titration of glargine, found that rates of glycemic control achieved in primary care settings were similar to rates achieved in specialist care settings. ${ }^{40}$

Several randomized trials have shown that protocols for self-titration of insulin by patients are effective in safely lowering $\mathrm{HbA}_{1 \mathrm{c}}{ }^{78-83}$ Patients using these self-titration algorithms coupled with daily blood glucose monitoring were able to achieve $\mathrm{HbA}_{1 \mathrm{c}}$ levels similar to those achieved in clinics, reducing their $\mathrm{HbA}_{\mathrm{lc}}$ by $1.0 \%$ to $2.5 \%$. A variety of insulin types were used in these studies, including 30/70 twice-daily insulin, ${ }^{79}$ detemir once daily, ${ }^{80}$ glargine once daily ${ }^{78,81}$ and rapidacting insulin before meals. ${ }^{83}$ Self-titration by patients resulted in similar rates of hypoglycemia compared with physician-managed titration, even though the patients used higher doses of insulin $(0.59$ units $/ \mathrm{kg}$ v. 0.40 units $/ \mathrm{kg}){ }^{80}{ }^{80}$ In one randomized controlled trial, self-titration was taught to individuals and to groups, with the two approaches achieving similar reductions in $\mathrm{HbA}_{\mathrm{lc}}$ (1.8\% and $2.0 \%$ respectively); the group sessions required half the time ${ }^{81}$ Regarding titration of bolus insulin, simple titration based on postprandial values was as effective as carbohydrate counting, lowering $\mathrm{HbA}_{1 \mathrm{c}}$ by $1.5 \%{ }^{83}$

The principles of insulin titration are described in Box 2, and sample protocols for insulin titration are described in Table 3. Insulin can be initiated in either primary care or specialist settings, and patients can titrate insulin doses

\section{Box 2: Principles of insulin titration by regimen}

Basal (intermediate- or long-acting insulin)

- Adjust the dose based on the fasting glucose level

Premixed insulin at breakfast and dinner

- Adjust the breakfast dose based on the previous dinner reading (as long as a dose increase does not cause hypoglycemia at lunchtime)

- Adjust the dinner dose based on the fasting glucose level (as long as a dose increase does not cause hypoglycemia at bedtime)

Basal-bolus*

- Adjust the dose at mealtime based on the previous day's glucose level measured either two hours after the corresponding mealtime or before the next mealtime (e.g,. adjust the breakfast dose based on the previous day's two-hour post-breakfast value or the prelunch value)

*Rapid- or short-acting insulin is used for bolus dose. 
themselves with no increased risk of hypoglycemia. Group sessions offer an efficient and effective alternative to individual counselling.

\section{Should oral antihyperglycemic agents be continued when initiating insulin therapy?}

Continuation of oral antihyperglycemic agents should be considered when initiating insulin therapy. The combination of therapies can result in greater $\mathrm{HbA}_{1 \mathrm{c}}$ reduction and lower daily insulin requirements.

Compared with insulin initiated alone, insulin combined with oral antihyperglycemic agents (except for thiazolidinediones) has comparable effects on glycemic control and better effects on weight gain, insulin dose and hypoglycemia.

In our analysis of studies comparing insulin alone or in combination with various oral antihyperglycemic agents (discussed in more detail later), we found no increased risk of adverse effects when insulin was combined with oral antihyperglycemic agents, with two exceptions. Combination therapy with insulin and thiazolidinediones (e.g., pioglitazone) was associated with greater weight gain, edema and possibly hypoglycemia; combination therapy with insulin and acarbose was associated with an increased risk of gastrointestinal upset. Appropriately powered data on morbidity and mortality, such as cardiovascular events, were not available.

\section{Metformin and secretagogues}

We identified 25 studies comparing insulin initiation alone or in combination with metformin or a secretagogue or both. ${ }^{18,22,31,33,37-39,45,54,55,77,84-97}$ In our meta-analysis, we found no significant reduction in $\mathrm{HbA}_{\mathrm{lc}}$ with a combination of an oral antihyperglycemic agent and insulin $(-0.14 \%, 95 \% \mathrm{CI}$ -0.36 to $0.08 ; n=2566) ;^{18,22,31,33,37-39,45,54,77,84-97}$ this effect was not moderated by class of oral antihyperglycemic agent or by insulin regimen. However, combination therapy was associated with significantly less weight gain $(-0.83 \mathrm{~kg}, 95 \% \mathrm{CI}$ -1.32 to $-0.33 ; n=2060)^{18,22,31,33,37-39,45,54,55,87-89,91,92,94-96}$ and significantly lower insulin doses $(-17.7$ units, $95 \%$ CI -26.1 to $-9.2 ; n=1308)$. ${ }^{18,31,33,37,39,54,87-89,91,92,94,95,97}$ It was also possibly associated with a reduced risk of hypoglycemia (OR $0.75,95 \%$ CI 0.56 to 1.00 ; $n=838)$. $22,33,39,84^{2}$

\section{Thiazolidinediones}

A recent meta-analysis comparing insulin initiation alone or in combination with pioglitazone

\begin{tabular}{|c|c|c|c|c|c|c|}
\hline \multirow[b]{2}{*}{ Regimen } & \multirow[b]{2}{*}{ Protocol } & \multirow[b]{2}{*}{ Starting dose } & \multicolumn{4}{|c|}{ Titration protocol } \\
\hline & & & Indicator & Adju & stment & $\begin{array}{l}\text { Adjustment } \\
\text { frequency }\end{array}$ \\
\hline \multirow[t]{2}{*}{ Basal } & INSIGHT $^{78}$ & 10 units at bedtime & $\begin{array}{l}\text { Fasting blood glucose: } \\
->5.5 \mathrm{mmol} / \mathrm{L}\end{array}$ & \multicolumn{2}{|l|}{ - +1 unit } & Daily \\
\hline & 303 algorithm ${ }^{80}$ & $\begin{array}{l}0.1-0.2 \text { units } / \mathrm{kg} \text { daily, } \\
\text { or } 10 \text { units once or } \\
\text { twice daily }\end{array}$ & $\begin{array}{l}\text { Average fasting } \\
\text { blood glucose: } \\
\text { - }<4.4 \mathrm{mmol} / \mathrm{L} \\
\text { - } 4.4-6.1 \mathrm{mmol} / \mathrm{L} \\
\text { - }>6.1 \mathrm{mmol} / \mathrm{L}\end{array}$ & \multicolumn{2}{|c|}{$\begin{array}{l}-3 \text { units } \\
\text { - No change } \\
\text { - }+3 \text { units }\end{array}$} & Every $3 \mathrm{~d}$ \\
\hline Premixed & INITIATEp/us ${ }^{79}$ & $\begin{array}{l}6 \text { units with breakfast } \\
\text { and supper }\end{array}$ & $\begin{array}{l}\text { Average blood glucose } \\
\text { level before breakfast } \\
\text { and before supper: } \\
\text { - }<4.4 \mathrm{mmol} / \mathrm{L} \\
\text { - } 4.4-6.1 \mathrm{mmol} / \mathrm{L} \\
\text { - } 6.2-7.8 \mathrm{mmol} / \mathrm{L} \\
\text { - } 7.9-10.0 \mathrm{mmol} / \mathrm{L} \\
\text { - }>10.0 \mathrm{mmol} / \mathrm{L}\end{array}$ & \multicolumn{2}{|c|}{$\begin{array}{l}-\quad-3 \text { units } \\
\text { - No change } \\
-\quad+3 \text { units } \\
-\quad+6 \text { units } \\
-\quad+9 \text { units }\end{array}$} & Every $3-5 d$ \\
\hline \multicolumn{7}{|c|}{$\begin{array}{l}\text { Basal-bolus } \\
\text { Basal (as above) }\end{array}$} \\
\hline Bolus & $\begin{array}{l}\text { Adjust to } \\
\text { target }^{83}\end{array}$ & $\begin{array}{l}50 \% \text { of total daily } \\
\text { dose, divided into } 3 \\
\text { doses ( } 50 \%, 33 \% \text { and } \\
17 \% \text { for largest, } \\
\text { medium and smallest } \\
\text { meal) }\end{array}$ & $\begin{array}{l}\text { Prandial insulin } \\
\text { dose: } \\
\text { - } \leq 10 \text { units } \\
\text { - } 11-19 \text { units } \\
\text { - } \geq 20 \text { units }\end{array}$ & $\begin{array}{l}\text { If at least half of } \\
\text { postprandial } \\
\text { values > target: } \\
\cdot+1 \text { unit } \\
-+2 \text { units } \\
-+3 \text { units }\end{array}$ & 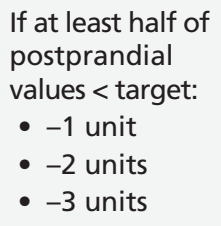 & Weekly \\
\hline
\end{tabular}


found that the combination therapy was associated with a significantly greater reduction in $\mathrm{HbA}_{1 \mathrm{c}}$ (mean difference $-0.58 \%, 95 \%$ CI $-0.70 \%$ to $-0.46 \%$ ), a trend toward lower daily insulin requirements ( -12 units daily) and higher HDL cholesterol levels (by 0.10 to $0.18 \mathrm{mmol} / \mathrm{L}$ ). ${ }^{98}$ However, it resulted in greater weight gain (mean difference $2.91 \mathrm{~kg}$, range $3.85 \mathrm{~kg}$ to $-3.50 \mathrm{~kg}$ ) and more peripheral edema; the effect on hypoglycemia was equivocal (relative risk 1.27, 95\% CI 0.99 to 1.63 ).

\section{Acarbose}

One trial examined insulin initiation combined with either acarbose or placebo. ${ }^{99}$ Compared with the patients in the placebo group, those given combination therapy with acarbose had a greater reduction in $\mathrm{HbA}_{1 \mathrm{c}}$ (difference $-0.50 \%, 95 \% \mathrm{CI}$ $-0.93 \%$ to $-0.07 \%$ ) and less weight gain (mean difference $-10.01 \mathrm{~kg}, 95 \% \mathrm{CI}-15.5 \mathrm{~kg}$ to -4.5 $\mathrm{kg}$ ), but a higher incidence of digestive disorders (40\% v. $17 \%) .{ }^{99}$

\section{Oral agents available for combined therapy with insulin}

Currently, acarbose is approved for combined therapy with insulin in both Canada and the United States. Pioglitazone, metformin and glimepiride are approved for combined use only in the United States. Other oral antihyperglycemic agents, such as dipeptidyl peptidase-IV (DPP-IV) inhibitors and glucagon-like peptide 1 (GLP1) agonists, are not approved for combination therapy with insulin in Canada or the United States.

\section{Unanswered questions}

Although glycemic control can improve morbidity and mortality among patients with type 2 diabetes, the impact of insulin, as well as the comparative effectiveness of different insulin strategies, on cardiovascular outcomes is unknown. Improved glycemic control is associated with an increased risk of hypoglycemia, and the optimal balance between the two remains unclear. Regimens that improve glycemic control often increase the complexity of treatment; limited data exist regarding the comparative effect of different strategies on quality of life and treatment satisfaction. Finally, effective and sustainable delivery of care has yet to be elucidated.

\section{Conclusion}

The choice of an insulin regimen and the timing of starting insulin therapy remain a discussion between the physician and patient. Factors such as accessibility, cost, patient preference and adverse effects (especially hypoglycemia and weight gain) must be considered. Box 3 provides an example of when and how to initiate insulin using the results of our literature review. Appendix 9 (available at www.cmaj.ca/lookup/suppl/doi:10.1503 /cmaj.110779/-/DC1) provides information on initiating insulin in older adults.

Future research on the effect of different insulin regimens on morbidity and mortality may further help us meet the individual needs of patients.

\section{Box 3: Applying the results of this review in clinical practice (fictional case)}

A 54-year-old man was diagnosed with type 2 diabetes 12 months ago with a presenting $\mathrm{HbA}_{1 \mathrm{c}}$ value of $9.8 \%$. At the time of diagnosis, he attended a diabetes education class, began taking metformin and gliclazide and started a walking program. To date, he has no identified macrovascular or microvascular complications of diabetes. Despite the use of the two oral antihyperglycemic agents, his $\mathrm{HbA}_{1 \mathrm{c}}$ value is $8.2 \%$, and his fasting blood glucose level is $9.8 \mathrm{mmol} / \mathrm{L}$. The findings on physical examination are normal except for obesity. Should insulin therapy be started? If so, what type and dosing regimen should be chosen?

- Insulin therapy is indicated because the addition of a third oral antihyperglycemic agent will likely not achieve the target $\mathrm{HbA}_{1 \mathrm{c}}$ value. Also, early intensive glycemic control reduces the risk of macrovascular and microvascular complications. The role of insulin is discussed with the patient. Although he is not worried about the increased self-monitoring of blood glucose levels required, he expresses a fear of becoming "addicted" to insulin. This fear is assuaged by further discussion regarding the natural history of diabetes.

- Given the patient's $\mathrm{HbA}_{1 \mathrm{c}}$ value of $8.2 \%$, a once-daily long-acting insulin is chosen because of its simplicity and its reduced risk of hypoglycemia. It is prescribed for use at bedtime for convenience. Although the patient is counselled about the off-label use of his oral antihyperglycemic agents in combination with insulin, he elects to continue using them, because combination therapy reduces weight gain, the risk of hypoglycemia and the insulin dose. He is told to start with 10 units of insulin and to increase the dose by 1 unit each day until his fasting blood glucose level is less than $7 \mathrm{mmol} / \mathrm{L}$.

At a brief follow-up visit one week later, the patient is found to be adapting well to the new regimen. His fasting blood glucose level is $8.7 \mathrm{mmol} / \mathrm{L}$, he has titrated his insulin dose to 17 units at bedtime, and he has had no hypoglycemic episodes. Three months later, he is injecting 26 units of insulin at bedtime, his $\mathrm{HbA}_{1 \mathrm{c}}$ value is on target at $6.9 \%$, and he reports improved energy and well-being. 


\section{References}

1. Shaw JE, Sicree RA, Zimmet PZ. Global estimates of the prevalence of diabetes for 2010 and 2030. Diabetes Res Clin Pract 2010;87:4-14

2. Gaede P, Lund-Andersen H, Parving HH, et al. Effect of a multifactorial intervention on mortality in type 2 diabetes. $N$ Engl J Med 2008:358:580-91.

3. Peyrot M, Rubin RR, Lauritzen T, et al. Resistance to insulin therapy among patients and providers: results of the crossnational Diabetes Attitudes, Wishes, and Needs (DAWN) study. Diabetes Care 2005;28:2673-9.

4. Canadian Diabetes Association Clinical Practice Guidelines Expert Committee. Canadian Diabetes Association 2008 clinical practice guidelines for the prevention and management of diabetes in Canada. Can J Diabetes 2008;32(Suppl 1):S1-201.

5. Nathan DM, Buse JB, Davidson MB, et al. Medical management of hyperglycemia in type 2 diabetes: a consensus algorithm for the initiation and adjustment of therapy: a consensus statement of the American Diabetes Association and the European Association for the Study of Diabetes. Diabetes Care 2009;32:193-203.

6. Clinical Guidelines Task Force. Global guideline for type 2 diabetes: recommendations for standard, comprehensive, and minimal care. Diabet Med 2006;23:579-93.

7. UK Prospective Diabetes Study (UKPDS) Group. Effect of intensive blood-glucose control with metformin on complications in overweight patients with type 2 diabetes (UKPDS 34). Lancet 1998;352:854-65.

8. Holman RR, Paul SK, Bethel MA, et al. 10-year follow-up of intensive glucose control in type 2 diabetes. N Engl J Med 2008; 359:1577-89.

9. Weng J, Li Y, Xu W, et al. Effect of intensive insulin therapy on beta-cell function and glycaemic control in patients with newly diagnosed type 2 diabetes: a multicentre randomised parallelgroup trial. Lancet 2008;371:1753-60.

10. Gerstein H, Yusuf S, Riddle MC, et al.; Origin Trial Investigators. Rationale, design, and baseline characteristics for a large international trial of cardiovascular disease prevention in people with dysglycemia: the ORIGIN Trial (Outcome Reduction with an Initial Glargine Intervention). Am Heart J 2008;155:26-32.

11. Seaquist ER, Ibrahim HN. Approach to the patient with type 2 diabetes and progressive kidney disease. J Clin Endocrinol Metab 2010;95:3103-10.

12. Garcia-Compean D, Jaquez-Quintana JO, Gonzalez-Gonzalez JA, et al. Liver cirrhosis and diabetes: risk factors, pathophysiology, clinical implications and management. World J Gastroenterol 2009; $15: 280-8$

14. Kann PH, Wascher T, Zackova V, et al. Starting insulin therapy in type 2 diabetes: twice-daily biphasic insulin Aspart 30 plus metformin versus once-daily insulin glargine plus glimepiride. Exp Clin Endocrinol Diabetes 2006;114:527-32.

15. Hermansen K, Davies M, Derezinski T, et al. A 26-week, randomized, parallel, treat-to-target trial comparing insulin detemir with NPH insulin as add-on therapy to oral glucose-lowering drugs in insulin-naive people with type 2 diabetes. Diabetes Care 2006;29:1269-74.

57. Cryer PE, Davis SN, Shamoon H. Hypoglycemia in diabetes. Diabetes Care 2003;26:1902-12.

43. Paterson KR, Wilson M, Kesson CM, et al. Comparison of basal and prandial insulin therapy in patients with secondary failure of sulphonylurea therapy. Diabet Med 1991;8:40-3.

30. Holman RR, Farmer AJ, Davies MJ, et al. Three-year efficacy of complex insulin regimens in type 2 diabetes. $N$ Engl $J$ Med 2009;361:1736-47.

58. Carver C. Insulin treatment and the problem of weight gain in type 2 diabetes. Diabetes Educ 2006;32:910-7.

59. UK Prospective Diabetes Study (UKPDS) Group. Intensive blood-glucose control with sulphonylureas or insulin compared with conventional treatment and risk of complications in patients with type 2 diabetes (UKPDS 33). Lancet 1998;352:837-53.

31. Olsson PO, Lindstrom T. Combination-therapy with bedtime $\mathrm{NPH}$ insulin and sulphonylureas gives similar glycaemic control but lower weight gain than insulin twice daily in patients with type 2 diabetes. Diabetes Metab 2002;28:272-7.

16. Birkeland KI, Rishaug U, Hanssen KF, et al. NIDDM: a rapid progressive disease. Results from a long-term, randomised, comparative study of insulin or sulphonylurea treatment. Diabetologia 1996;39:1629-33.

60. Cohen O, Norymberg C, Neumann E, et al. Weight gain in type 2 diabetes mellitus - Not all uphill. Diabetes Res Clin Pract 2008;79:128-32.

61. Birkeland KI, Hanssen KF, Urdal P, et al. A long-term, randomized, comparative study of insulin versus sulfonylurea therapy in type 2 diabetes. J Intern Med 1994;236:305-13.
62. Yki-Järvinen H, Ryysy L, Kauppila M, et al. Effect of obesity on the response to insulin therapy in noninsulin-dependent diabetes mellitus. J Clin Endocrinol Metab 1997;82:4037-43.

13. Nakar S, Yitzhaki G, Rosenberg R, et al. Transition to insulin in type 2 diabetes: family physicians' misconception of patients fears contributes to existing barriers. J Diabetes Complications 2007;21:220-6

17. Groop L, Widen E, Franssila-Kallunki A, et al. Different effects of insulin and oral antidiabetic agents on glucose and energy metabolism in type 2 (non-insulin-dependent) diabetes mellitus. Diabetologia 1989;32:599-605.

18. Yki-Järvinen H, Kauppila M, Kujansuu E, et al. Comparison of insulin regimens in patients with non-insulin-dependent diabetes mellitus. N Engl J Med 1992;327:1426-33.

19. Hendra TJ, Taylor CD. A randomised trial of insulin on wellbeing and carer strain in elderly type 2 diabetic subjects. J Diabetes Complications 2004;18:148-54.

20. Rodier M, Colette C, Gouzes C, et al. Effects of insulin therapy upon plasma lipid fatty acids and platelet aggregation in NIDDM with secondary failure to oral antidiabetic agents. Diabetes Res Clin Pract 1995;28:19-28.

21. Harris S, Yale JF, Dempsey E, et al. Can family physicians help patients initiate basal insulin therapy successfully? Randomized trial of patient-titrated insulin glargine compared with standard oral therapy: lessons for family practice from the Canadian INSIGHT trial. Can Fam Physician 2008;54:550-8.

22. Ushakova O, Sokolovskaya V, Morozova A, et al. Comparison of biphasic insulin aspart 30 given three times daily or twice daily in combination with metformin versus oral antidiabetic drugs alone in patients with poorly controlled type 2 diabetes: a 16-week, randomized, open-label, parallel-group trial conducted in Russia. Clin Ther 2007;29:2374-84

23. Papa G, Fedele V, Chiavetta A, et al. Therapeutic options for elderly diabetic subjects: open label, randomized clinical trial of insulin glargine added to oral antidiabetic drugs versus increased dosage of oral antidiabetic drugs. Acta Diabetol 2008;45:53-9.

24. Ko GT, Tsang PC, Wai HP, et al. Rosiglitazone versus bedtime insulin in the treatment of patients with conventional oral antidiabetic drug failure: a 1-year randomized clinical trial. Adv Ther 2006;23:799-808.

25. Schwartz S, Sievers R, Strange P, et al. Insulin 70/30 mix plus metformin versus triple oral therapy in the treatment of type 2 diabetes after failure of two oral drugs: efficacy, safety, and cost analysis. Diabetes Care 2003;26:2238-43.

26. Alvarsson M, Sundkvist G, Lager I, et al. Effects of insulin v. glibenclamide in recently diagnosed patients with type 2 diabetes: a 4-year follow-up. Diabetes Obes Metab 2008;10:421-9.

27. Raz I, Stranks S, Filipczak R, et al. Efficacy and safety of biphasic insulin aspart 30 combined with pioglitazone in type 2 diabetes poorly controlled on glibenclamide (glyburide) monotherapy or combination therapy: an 18-week, randomized, open-label study. Clin Ther 2005;27:1432-43.

28. Ovalle F, Bell DS. Effect of rosiglitazone versus insulin on the pancreatic beta-cell function of subjects with type 2 diabetes. Diabetes Care 2004;27:2585-9.

29. Klein W. Sulfonylurea-metformin-combination versus sulfonylurea-insulin-combination in secondary failures of sulfonylurea monotherapy. Results of a prospective randomized study in 50 patients. Diabete Metab 1991;17:235-40.

63. Pibernik-Okanovic M, Szabo S, Metelko Z. Quality of life following a change in therapy for diabetes mellitus. Pharmacoeconomics 1998;14:201-7.

64. Houlden R, Ross S, Harris S, et al. Treatment satisfaction and quality of life using an early insulinization strategy with insulin glargine compared to an adjusted oral therapy in the management of type 2 diabetes: the Canadian INSIGHT Study. Diabetes Res Clin Pract 2007;78:254-8.

65. Taylor R, Foster B, Kyne-Grzebalski D, et al. Insulin regimens for the non-insulin dependent: impact on diurnal metabolic state and quality of life. Diabet Med 1994;11:551-7.

66. Brunton S. Insulin delivery systems: reducing barriers to insulin therapy and advancing diabetes mellitus treatment. Am J Med 2008;121(Suppl):S35-41.

67. Brown JB, Harris SB, Webster-Bogaert S, et al. The role of patient, physician and systemic factors in the management of type 2 diabetes mellitus. Fam Pract 2002;19:344-9.

68. Peyrot M, Rubin RR, Khunti K. Addressing barriers to initiation of insulin in patients with type 2 diabetes. Prim Care Diabetes 2010;4(Suppl 1):S11-8.

69. Brown SA. Meta-analysis of diabetes patient education research: variations in intervention effects across studies. Res Nurs Health 1992;15:409-19.

70. Brown SA. Effects of educational interventions in diabetes care: a meta-analysis of findings. Nurs Res 1988;37:223-30. 
71. Shah BR, Hux JE, Laupacis A, et al. van WC. Diabetic patients with prior specialist care have better glycaemic control than those with prior primary care. J Eval Clin Pract 2005;11:568-75.

72. Shojania KG, Ranji SR, McDonald KM, et al. Effects of quality improvement strategies for type 2 diabetes on glycemic control: a meta-regression analysis. JAMA 2006;296:427-40

73. Weber C. Challenges in funding diabetes care: a health economic perspective. Expert Rev Pharmacoecon Outcomes Res 2010;10:517-24

32. Kazda C, Hulstrunk H, Helsberg K, et al. Prandial insulin substitution with insulin lispro or insulin lispro mid mixture $\mathrm{v}$. basal therapy with insulin glargine: a randomized controlled trial in patients with type 2 diabetes beginning insulin therapy. $J$ Diabetes Complications 2006;20:145-52

33. Janka HU, Plewe G, Riddle MC, et al. Comparison of basal insulin added to oral agents versus twice-daily premixed insulin as initial insulin therapy for type 2 diabetes. Diabetes Care 2005; 28:254-9.

34. Raskin P, Allen E, Hollander P, et al. Initiating insulin therapy in type 2 diabetes: a comparison of biphasic and basal insulin analogs. Diabetes Care 2005;28:260-5.

35. Buse JB, Wolffenbuttel BH, Herman WH, et al. DURAbility of basal versus lispro mix 75/25 insulin efficacy (DURABLE) trial 24-week results: safety and efficacy of insulin lispro mix 75/25 versus insulin glargine added to oral antihyperglycemic drugs in patients with type 2 diabetes. Diabetes Care 2009;32:1007-13.

36. Wolffenbuttel BH, Klaff LJ, Bhushan $\mathrm{R}$, et al. Initiating insulin therapy in elderly patients with type 2 diabetes: efficacy and safety of lispro mix $25 \mathrm{v}$. basal insulin combined with oral glucose-lowering agents. Diabet Med 2009;26:1147-55.

37. Goudswaard AN, Stolk RP, Zuithoff P, et al. Starting insulin in type 2 diabetes: continue oral hypoglycemic agents? A randomized trial in primary care. J Fam Pract 2004;53:393-9.

38. Milicevic Z, Hancu N, Car N, et al. Effect of two starting insulin regimens in patients with type 2 diabetes not controlled on a combination of oral antihyperglycemic medications. Exp Clin Endocrinol Diabetes 2009; 117:223-9.

39. Stehouwer MH, DeVries JH, Lumeij JA, et al. Combined bedtime insulin-daytime sulphonylurea regimen compared with two different daily insulin regimens in type 2 diabetes: effects on $\mathrm{HbA1c}$ and hypoglycaemia rate - a randomised trial. Diabetes Metab Res Rev 2003;19:148-52.

40. Davies M, Evans R, Storms F, et al. Initiation of insulin glargine in suboptimally controlled patients with type 2 diabetes: subanalysis of the AT.LANTUS trial comparing treatment outcomes in subjects from primary and secondary care in the UK. Diabetes Obes Metab 2007:9:706-13.

41. Strojek K, Bebakar WM, Khutsoane DT, et al. Once-daily initiation with biphasic insulin aspart 30 versus insulin glargine in patients with type 2 diabetes inadequately controlled with oral drugs: an open-label, multinational RCT. Curr Med Res Opin 2009;25:2887-94.

42. Kilo C, Mezitis N, Jain R, et al. Starting patients with type 2 diabetes on insulin therapy using once-daily injections of biphasic insulin aspart 70/30, biphasic human insulin 70/30, or NPH insulin in combination with metformin. J Diabetes Complications 2003; 17:307-13

44. Landstedt-Hallin L, Adamson U, Arner P, et al. Comparison of bedtime NPH or preprandial regular insulin combined with glibenclamide in secondary sulfonylurea failure. Diabetes Care 1995; 18:1183-6.

45. Bastyr EJ III, Johnson ME, Trautmann ME, et al. Insulin lispro in the treatment of patients with type 2 diabetes mellitus after oral agent failure. Clin Ther 1999;21:1703-14.

46. Bretzel RG, Nuber U, Landgraf W, et al. Once-daily basa insulin glargine versus thrice-daily prandial insulin lispro in people with type 2 diabetes on oral hypoglycaemic agents (APOLLO): an open randomised controlled trial. Lancet 2008, 371:1073-84.

47. Abrahamian H, Ludvik B, Schernthaner G, et al. Improvement of glucose tolerance in type 2 diabetic patients: traditional v. modern insulin regimens (results from the Austrian Biaspart Study). Horm Metab Res 2005;37:684-9.

48. Esposito K, Ciotola M, Maiorino MI, et al. Addition of neutral protamine lispro insulin or insulin glargine to oral type 2 diabetes regimens for patients with suboptimal glycemic control: a randomized trial. Ann Intern Med 2008;149:531-9.

49. Philis-Tsimikas A, Charpentier G, Clauson P, et al. Comparison of once-daily insulin detemir with NPH insulin added to a regimen of oral antidiabetic drugs in poorly controlled type 2 diabetes. Clin Ther 2006;28:1569-81.

50. Yki-Järvinen H, Dressler A, Ziemen M. Less nocturnal hypoglycemia and better post-dinner glucose control with bedtime insulin glargine compared with bedtime NPH insulin during insulin combination therapy in type 2 diabetes. HOE 901/3002 Study Group. Diabetes Care 2000;23:1130-6.

51. Taylor R, Davies R, Fox C, et al. Appropriate insulin regimes for type 2 diabetes: a multicenter randomized crossover study. Dia betes Care 2000;23:1612-8.

52. Riddle MC, Rosenstock J, Gerich J. The treat-to-target trial: randomized addition of glargine or human NPH insulin to oral therapy of type 2 diabetic patients. Diabetes Care 2003;26:3080-6.

53. Massi Benedetti M, Humburg E, Dressler A, et al. A one-year, randomised, multicentre trial comparing insulin glargine with NPH insulin in combination with oral agents in patients with type 2 diabetes. Horm Metab Res 2003;35:189-96.

74. Horvath K, Jeitler K, Berghold A, et al. Long-acting insulin analogues versus NPH insulin (human isophane insulin) for type 2 diabetes mellitus. Cochrane Database Syst Rev 2007; (2):CD005613.

75. Raskin P, Gylvin T, Weng W, et al. Comparison of insulin detemir and insulin glargine using a basal-bolus regimen in a randomized, controlled clinical study in patients with type 2 diabetes. Diabetes Metab Res Rev 2009;25:542-8.

76. Swinnen SG, Dain MP, Aronson R, et al. A 24-week, randomized, treat-to-target trial comparing initiation of insulin glargine once-daily with insulin detemir twice-daily in patients with type 2 diabetes inadequately controlled on oral glucose-lowering drugs. Diabetes Care 2010;33:1176-8.

54. Wolffenbuttel BH, Sels JP, Rondas-Colbers GJ, et al. Comparison of different insulin regimens in elderly patients with NIDDM. Diabetes Care 1996;19:1326-32.

55. Zargar AH, Masoodi SR, Laway BA, et al. Response of regimens of insulin therapy in type 2 diabetes mellitus subjects with secondary failure. J Assoc Physicians India 2002;50:641-6.

56. Diabetes Control and Complications Trial Research Group Hypoglycemia in the Diabetes Control and Complications Trial. Diabetes 1997;46:271-86.

77. Altuntas Y, Ozen B, Ozturk B, et al. Comparison of additional metformin or NPH insulin to mealtime insulin lispro therapy with mealtime human insulin therapy in secondary OAD failure. Diabetes Obes Metab 2003;5:371-8.

84. Davies MJ, Thaware PK, Tringham JR, et al. A randomized controlled trial examining combinations of repaglinide, metformin and NPH insulin. Diabet Med 2007;24:714-9.

78. Gerstein HC, Yale JF, Harris SB, et al. A randomized trial of adding insulin glargine $\mathrm{v}$. avoidance of insulin in people with type 2 diabetes on either no oral glucose-lowering agents or submaximal doses of metformin and/or sulphonylureas. The Canadian INSIGHT (Implementing New Strategies with Insulin Glargine for Hyperglycaemia Treatment) Study. Diabet Med 2006;23:736-42.

79. Oyer DS, Shepherd MD, Coulter FC, et al. A(1c) control in a primary care setting: self-titrating an insulin analog pre-mix (INITIATEplus trial). Am J Med 2009;122:1043-9.

80. Selam JL, Koenen C, Weng W, et al. Improving glycemic control with insulin detemir using the 303 Algorithm in insulin naive patients with type 2 diabetes: a subgroup analysis of the US PREDICTIVE 303 study. Curr Med Res Opin 2008;24:11-20.

81. Yki-Järvinen H, Juurinen L, Alvarsson M, et al. Initiate Insulin by Aggressive Titration and Education (INITIATE): a randomized study to compare initiation of insulin combination therapy in type 2 diabetic patients individually and in groups. Diabetes Care 2007;30:1364-9.

82. Davies M, Storms F, Shutler S, et al. Improvement of glycemic control in subjects with poorly controlled type 2 diabetes: comparison of two treatment algorithms using insulin glargine. Diabetes Care 2005;28:1282-8.

83. Bergenstal RM, Johnson M, Powers MA, et al. Adjust to target in type 2 diabetes: comparison of a simple algorithm with carbohydrate counting for adjustment of mealtime insulin glulisine. Diabetes Care 2008;31:1305-10.

85. Sun Y, Xiong Y, Yang J. The effectiveness of combined insulin and sulfonylurea in treating non-insulin dependent diabetic patients. Zhonghua Nei Ke Za Zhi 1995;34:246-9.

86. Wolffenbuttel BH, Rondas-Colbers GJ, Menheere PP, et al. The effects of insulin combined with glibenclamide on glucose and lipid metabolism in patients with type 2 diabetes mellitus. Ned Tijdschr Geneeskd 1991;135:1080-4.

87. Douek IF, Allen SE, Ewings P, et al. Continuing metformin when starting insulin in patients with type 2 diabetes: a double-blind randomized placebo-controlled trial. Diabet Med 2005;22:634-40.

88. Civera M, Merchante A, Salvador M, et al. Safety and efficacy of repaglinide in combination with metformin and bedtime NPH insulin as an insulin treatment regimen in type 2 diabetes. Diabetes Res Clin Pract 2008;79:42-7.

89. Yki-Järvinen H, Ryysy L, Nikkila K, et al. Comparison of bedtime insulin regimens in patients with type 2 diabetes mellitus. A randomized, controlled trial. Ann Intern Med 1999;130:389-96. 
90. Fövényi J, Grosz A, Thaisz E, et al. [Daytime sulfonyluyrea bedtime insulin combination therapy in type 2 diabetes.] Magy Belorv Arch (Hungarian Archive of Internal Medicine) 1997;50: 607-13.

91. Riddle M, Hart J, Bingham P, et al. Combined therapy for obese type 2 diabetes: suppertime mixed insulin with daytime sulfonylurea. Am J Med Sci 1992;303:151-6.

92. Shank ML, Del PS, DeFronzo RA. Bedtime insulin/daytime glipizide. Effective therapy for sulfonylurea failures in NIDDM. Diabetes 1995;44:165-72.

93. Xu WC, Chen CR, Chen YS. Combination therapy with bedtime insulin and daytime oral hypoglycaemic agests in type 2 diabetic patients. Hebei Med J 2001:23-4.

94. Kabadi MU, Kabadi UM. Efficacy of sulfonylureas with insulin in type 2 diabetes mellitus. Ann Pharmacother 2003;37:1572-6.

95. Riddle MC, Schneider J. Beginning insulin treatment of obese patients with evening 70/30 insulin plus glimepiride versus insulin alone. Glimepiride Combination Group. Diabetes Care 1998;21:1052-7.

96. Chow CC, Tsang LW, Sorensen JP, et al. Comparison of insulin with or without continuation of oral hypoglycemic agents in the treatment of secondary failure in NIDDM patients. Diabetes Care 1995; 18:307-14

97. Lotz N, Bachmann W, Ladik T, et al. Combination therapy with insulin/sulfonylurea in the long-term therapy of type 2 diabetes following "secondary failure." Klin Wochenschr 1988;66:1079-84.

98. Clar C, Royle P, Waugh N. Adding pioglitazone to insulin containing regimens in type 2 diabetes: systematic review and metaanalysis. PLOS ONE 2009;4:e6112.
99. Schnell O, Mertes G, Standl E. Acarbose and metabolic control in patients with type 2 diabetes with newly initiated insulin therapy. Diabetes Obes Metab 2007;9:853-8.

Affiliations: From the Department of Medicine (Lau, Tang, Yu), University of Toronto; St. Michael's Hospital (Halapy, Yu); Keenan Research Centre in the Li Ka Shing Knowledge Institute of St. Michael's Hospital (Thorpe, Yu); Dalla Lana School of Public Health (Yu), University of Toronto, Toronto, Ont.

Contributors: Adrian Lau participated in the literature searches, reviewed abstracts, analyzed and synthesized the results and drafted portions of the manuscript. Terence Tang abstracted data, assisted with statistical interpretation and drafted portions of the manuscript. Henry Halapy abstracted data and drafted portions of the manuscript. Kevin Thorpe performed statistical analyses and drafted portions of the manuscript. Catherine Yu participated in the literature searches, reviewed abstracts, abstracted data, analyzed and synthesized the results and drafted the manuscript. All of the authors critically reviewed the manuscript and approved the final version submitted for publication.

Acknowledgements: The authors thank Laure Perrier for performing the literature search and Jisun Oh for participating in the review of abstracts.

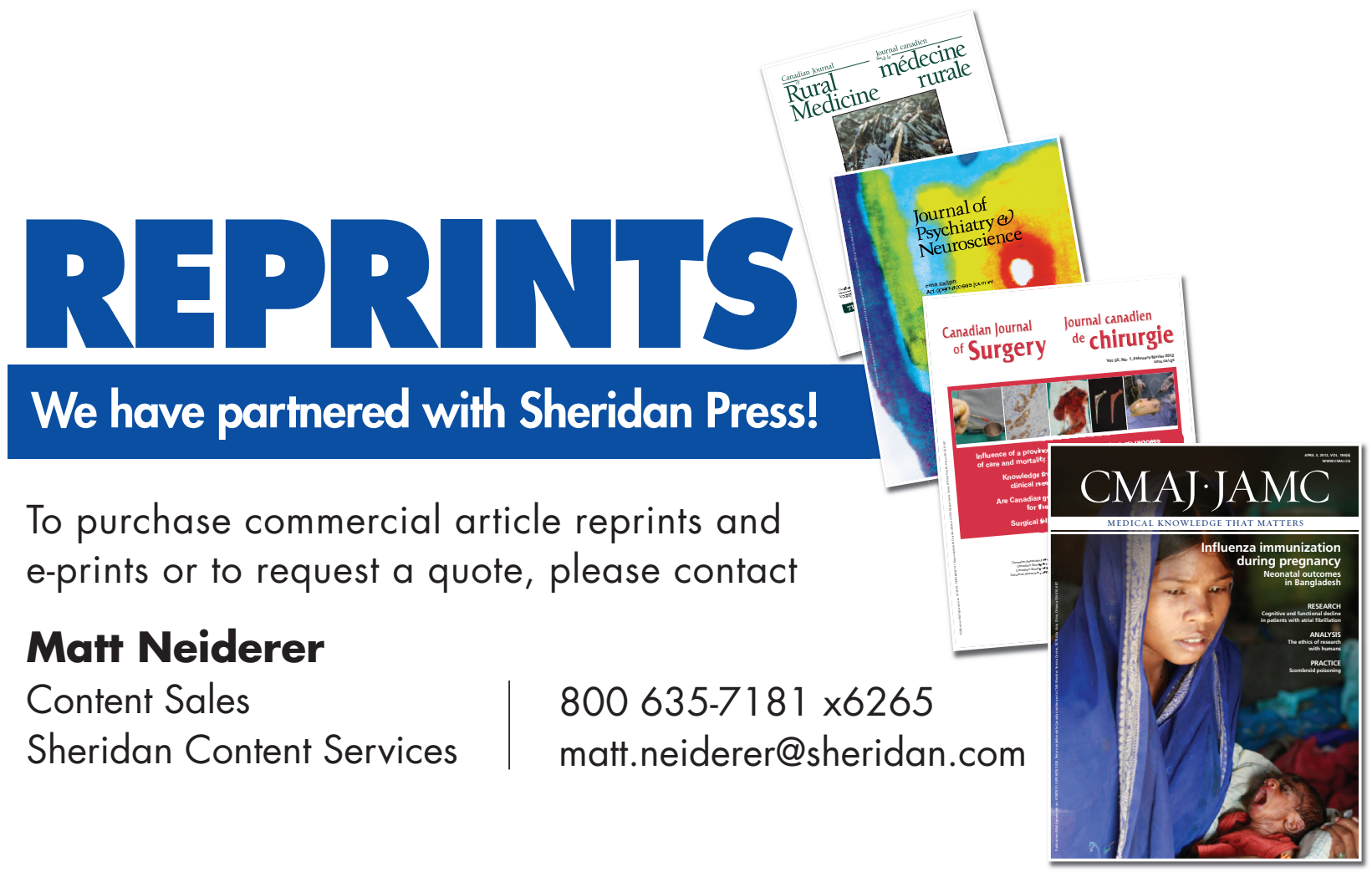

